\title{
Rho kinase inhibitors for glaucoma treatment - Review
}

\author{
Inibidores da Rho-Quinase para o tratamento do glaucoma-Revisão
}

Renato Antunes Schiave Germano ${ }^{1}$, Simone Finzl ${ }^{1}$, Pratap Challa $^{2}$, Remo Susanna Junior ${ }^{1}$

\begin{abstract}
Glaucoma is a progressive optic neuropathy characterized by the loss of ganglion cells and their axons. A major risk factor for glaucomatous visual field loss is elevated intraocular pressure (IOP), and several studies have shown that lowering IOP reduces the risk of glaucomatous progression. Currently, an increasing number of researches involve Rho kinase inhibitors, which are a new pharmacological class of hypotensive agents specifically targeting the diseased trabecular outflow pathway. Rho kinase inhibitors reduce IOP by increasing aqueous humor drainage through the primary outflow pathway in the eye, which is known as the trabecular meshwork. In addition to improving the outflow facility of the trabecular meshwork, Rho kinase inhibitors also enhance retinal ganglion cell survival after ischemic injury and increase ocular blood flow.
\end{abstract}

Keywords: Glaucoma; Intraocular pressure; Rho-associated kinases; Aqueous humor; Trabecular meshwork

\section{RESUMO}

Glaucoma é uma neuropatia óptica progressiva, caracterizada pela perda de células ganglionares e seus axônios. O principal fator de risco que leva à perda de campo visual relacionada ao glaucoma é a elevação da pressão intraocular (PIO) e vários estudos mostraram que a redução da pressão intraocular diminui o risco de progressão do glaucoma. Atualmente, uma nova classe de drogas hipotensoras foi desenvolvida e tem sido cada vez mais estudada, os inibidores da Rho-Kinase. Essas drogas reduzem a pressão intraocular aumentando a drenagem de humor aquoso através da via de drenagem primária do humor aquoso no olho, a malha trabecular. Além de aumentar o escoamento pela malha trabecular, inibidores da Rho-kinase também aumentam a sobrevivência das células ganglionares retinianas após isquemia e aumentam o fluxo ocular sanguíneo.

Descritores: Glaucoma; Pressão intraocular; Quinases associadas a Rho; Humor aquoso; Malha trabecular

\section{INTRODUCTION}

Glaucoma is a progressive optic neuropathy characterized by the loss of ganglion cells and their axons, resulting in a distinctive appearance of the optic disc. Glaucoma is concomitant to visual loss and is the second leading cause of blindness in the world $d^{(1,2)}$. The disease affected more than 60.5 million individuals in 2010 and is projected to reach 79.6 million by the year $2020^{(2)}$. Glaucoma is almost always asymptomatic, particularly during the early stages, which is why it remains undiagnosed in up to half of the total cases in developed nations, with even higher undiagnosed rates in parts of the developing world ${ }^{(3,4)}$.

A major risk factor for glaucomatous visual field loss is elevated intraocular pressure $(I O P)^{(5)}$, and several studies have shown that lowering IOP reduces the risk of glaucomatous progression ${ }^{(6,7)}$. Eye drops, oral medications, laser therapy, and surgery have all been used to decrease IOP in glaucoma patients.

Currently, there are five main classes of eye drops for IOP reduction: cholinergic (pilocarpine), $\beta$-blockers, a-agonists, carbonic anhydrase inhibitors, and prostaglandin analogs. However, for many patients, these medications in monotherapy do not effectively control IOP, and approximately half of patients with elevated IOP are treated by co-administration of two or more glaucoma medications ${ }^{(8)}$. Further, all of these classes of eye drops present ocular and systemic adverse effects that can impair the effectiveness of the treatment. Therefore, researchers are currently searching for new IOP-lowering drugs.
At present, the available pharmacological treatments for glaucoma lower IOP either by decreasing the production of aqueous humor via the ciliary process (i.e., $\beta$-blocker agents, carbonic anhydrase inhibitors, and a-agonists) or by improving aqueous humor outflow via an unconventional pathway (i.e., prostaglandin analogs) ${ }^{(9-12)}$. Muscarinic agonists, such as pilocarpine, can increase aqueous humor drainage via the conventional outflow pathway by contracting the ciliary muscle and pulling on the sclera spur to favorably change the architecture of the tissues of the conventional outflow pathway. However, there are no pharmacological agents that specifically target the diseased trabecular outflow pathway.

Small-molecule inhibitors of Rho-associated protein kinase (ROCK) are a new drug class that have recently been studied as potential glau-

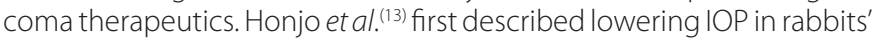
eyes using a selective ROCK inhibitor, Y-27632. ROCK inhibitors reduce IOP by increasing aqueous humor drainage through the primary outflow pathway in eyes, which is known as the trabecular meshwork $(T M)^{(14)}$. In addition to improving the outflow facility of the TM, ROCK inhibitors also enhance retinal ganglion cell survival after ischemic injury $y^{(15,16)}$ and increase ocular blood flow ${ }^{(17)}$. Due to these functions, ROCK inhibitors have recently gained interest and are the focus of several ongoing clinical trials.

\section{Physiology of Aqueous humor outflow}

The balance between the inflow and outflow of aqueous humor is responsible for IOP. Once produced, aqueous humor migrates from

\footnotetext{
Submitted for publication: August 4, 2015

Accepted for publication: October 1, 2015

Ophthalmology Department. Universidade de São Paulo (USP), São Paulo, SP, Brazil.

2 Duke University Eye Center, Durham, NC, USA.
}

Funding: No specific financial support was available for this study.

Disclosure of potential conflicts of interest: None of the authors have any potential conflict of interest to disclose.

Corresponding author: Renato A. S. Germano. Av. Dr. Eneas de Carvalho Aguiar, 255 - São Paulo, SP - 05403-001 - Brazil -E-mail: rasgermano@hotmail.com 
the posterior chamber to the anterior chamber, where it is drained out of the eye. There are two aqueous humor outflow pathways in the eye. Under normal conditions, the TM is responsible for the majority of the aqueous humor outflow ${ }^{(18,19)}$. An auxiliary "unconventional" uveoscleral pathway exists through the iris root and ciliary muscle, but it carries less than $10 \%$ of the total aqueous humor flow in the eye $e^{(20)}$.

The TM can be subdivided into three regions: the uveal meshwork, corneoscleral meshwork, and juxtacanalicular connective tissue (JCT). After passing through the TM, the aqueous humor drains through Schlemm's canal (SC) and then enters the systemic circulation through the episcleral veins. An increased resistance to flow in the conventional pathway (which carries up to $90 \%$ of the total aqueous humor out of the eye) is predominantly responsible for the elevated IOP in many types of glaucoma. In primary open-angle glaucoma (POAG), the most common type, increased outflow resistance has been classically associated with the juxtacanalicular portion of the TM mediated through the extracellular matrix (ECM) as well as in the endothelial-lined SC ${ }^{(21,22)}$. Morphologically, the TM is a complex tissue consisting of TM cells, ECM, and empty spaces, which the aqueous humor runs through. These spaces gradually become smaller as they get closer to SC, and the density of the TM cells and ECM is relatively high in this area, resulting in a higher resistance to flow. The tissues of the conventional outflow pathway have unique morphological and functional properties with subtle complexities ${ }^{(23)}$. The functional properties of the TM are often affected in individuals of increasing age and those with ocular disease, such as POAG ${ }^{(24)}$.

Besides the simple static anatomy of the aqueous humor flow, the conventional outflow pathway is also influenced by the contraction of the ciliary muscle when exposed to a muscarinic agent such as pilocarpine. When the ciliary muscle contracts, its insertions widen the intercellular spaces in the TM and the permeability of the tissue increases; simultaneously, the uveoscleral outflow decreases ${ }^{(25)}$. However, other studies have shown that the TM is also thought to have a dynamic regulatory mechanism due to its smooth-muscle-like properties, as evidenced by the expression of a-smooth muscle actin and myosin, ion channels, and G-protein-coupled receptors in TM cells ${ }^{(26,27)}$. Moreover, physiological contractile agonists, cytokines, growth factors, as well as pharmacological agents, have been shown to influence the contractile and relaxation properties of TM tissue ${ }^{(26,28)}$. Based on perfusion studies using anterior segments of the eye, the TM alone has been shown to participate in the regulation of aqueous outflow through SC ${ }^{(29,30)}$. The actomyosin system, composed of the contractile proteins actin and myosin, is responsible for regulating contraction and relaxation in muscle tissues, and this system is present in the TM and JCT/SC. In addition, the contractile and relaxation power of the TM influences aqueous humor outflow in an antagonistic manner ${ }^{(26,31)}$. Relaxation of the TM relaxes the cellular actomyosin system, resulting in cellular relaxation and/or cell shape alteration, which increases the size of the intercellular spaces, leading to increased aqueous outflow ${ }^{(25,26)}$.

The concentration of transforming growth factor $\beta$ (TGF- $\beta$ ) in the aqueous humor of glaucomatous patients is higher than that in healthy controls, and TGF- $\beta$ is believed to play an important role in the pathogenesis of glaucoma ${ }^{(32-34)}$. Other bioactive endogenous mediators of contractility molecules, such as cytokines and endothelin, are also present in higher concentrations in glaucomatous eyes ${ }^{(35)}$.

\section{RHO KINASE SIGNALING IN SMOOTH MUSCLE CONTRACTION}

The regulation of TM contractility is controlled by both calcium-dependent and calcium-independent mechanisms. Smooth muscle contraction is known to be predominantly regulated by the phosphorylation of myosin light chain (MLC). MLC is phosphorylated by calcium/calmodulin-dependent MLC kinase (MLCK) and dephosphorylated by calcium-independent MLC phosphatase (MLCP) ${ }^{(36)}$ Besides this regulation by $\mathrm{Ca}^{2+}$ concentration, $\mathrm{MLC}$ phosphorylation can be modulated via signaling pathways such as the Rho/Rho kinase pathway.

Downstream effectors of Rho include the ROCKs, which are protein-serine/threonine kinases. Structurally, ROCKs are composed of three major domains: an N-terminal kinase domain that phosphorylates protein targets, a C-terminal auto-inhibitory domain that limits kinase activity via intermolecular interactions, and a coiled-coil Rho-binding domain that appears to facilitate the switch from the inactive to the active conformation (Figure 1)(37). ROCKs can phosphorylate the same serine residue of MLC phosphorylated by MLCK ${ }^{(37)}$ in a manner independent of calcium concentrations, leading to enhanced smooth muscle contraction. Further, ROCKs can phosphorylate myosin phosphatase, which leads to its inactivation.

\section{ROCK INHIBITORS}

TM and ciliary muscle tissue are known to express many components of the Rho signaling pathway, such as ROCK1 and ROCK2, RhoA, $M L C, M L C K$, and MLCP(38). Thus, ROCK activity through the Rho signaling pathway is thought to be a key player in regulating the cellular morphology and contractility of the conventional outflow pathway. ROCK inhibitors are the first class of glaucoma drugs to increase aqueous humor outflow by working directly on the TM and SC cells, thus lowering IOP. Different ROCK inhibitors (Y-27632, H-1152, and fasudil) have been shown to induce rapid and long-lasting lowering of IOP (within 30 min and lasting for 6-12 h) in various animal models, including rabbit and monkey ${ }^{(39-41)}$.

The exact mechanism by which Rho inhibitors increase the outflow facility through the conventional pathway is not completely understood. It is hypothesized that by inhibiting ROCK, specific components of the cellular cytoskeleton are disrupted, thus reducing the contractile tone of the tissues of the conventional outflow pathway. The final effect of these two mechanisms would be the increase of the paracellular fluid flow through the inner wall of the SC due to the altered cell shape and cell junctions and the relaxation of the TM and JCT, thereby leading to an increase in outflow facility and a lowering of IOP.

\section{Other applications of ROCK inhibitors}

Several studies have shown that ROCK inhibitors may also benefit glaucoma patients by improving the ocular blood flow as well as presenting potential neuroprotective effects; there is also evidence showing that they may prevent postoperative scarring after glaucoma filtration surgery ${ }^{(42,43)}$. ROCK inhibitors increase blood flow under systemic hypertensive conditions via relaxation of vascular endothelial smooth muscle. As altered ocular blood flow is believed to be key to the pathophysiology of certain types of glaucoma ${ }^{(44)}$, ROCK inhibitors could provide additional benefit as therapeutics agents for glaucoma.

ROCK inhibitors have also been shown to play roles in neuron survival and axon regeneration ${ }^{(45)}$. Finally, ROCK inhibitors have been

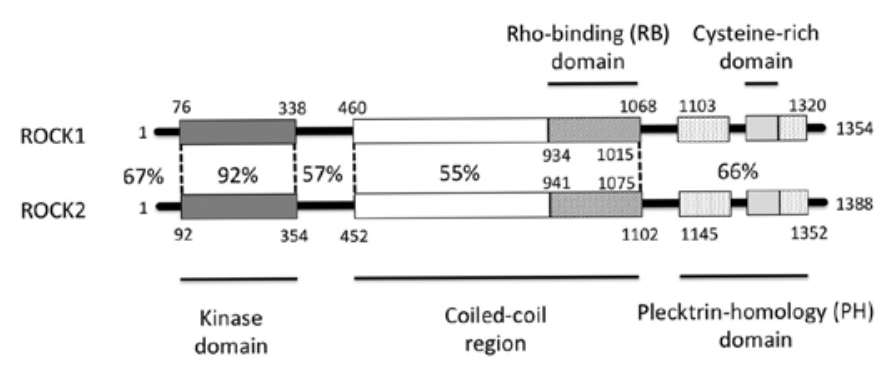

Figure 1. Structures of ROCK isoforms. Modified from Liao JK, Seto M, Noma K. Rho kinase (ROCK) inhibitors. J Cardiovasc Pharmacol 2007;50(1):17-24(3) 
reported to blockTGF- $\beta$ myofibroblast transdifferentiation of human tendon fibroblasts, which suggests that ROCK inhibitors may reduce postoperative scarring after glaucoma filtration surgery ${ }^{(46)}$.

\section{UNDESIRABLE EFFECTS OF ROCK}

ROCK inhibitors have been shown to be potent vasodilators, including in the conjunctival vasculature. Arnold et al.(47) studied the effects of Y-27632 on the intraocular penetration of timolol maleate, and they found that ROCK inhibitors reduced the intraocular penetration of timolol, presumably due to increased systemic elimination through the conjunctival vasculature.

Bacharach et al. ${ }^{(48)}$ evaluated the efficacy and safety of AR-13324 ophthalmic solution in terms of ocular hypertension $(\mathrm{OH})$ compared with a control group using latanoprost in patients with open-angle glaucoma or $\mathrm{OH}$. Patients were randomized to receive AR-13324 ophthalmic solution $0.01 \%$, daily (pm), AR-13324 ophthalmic solution $0.02 \%$ daily $(\mathrm{pm})$, or latanoprost $0.005 \%$ daily $(\mathrm{pm})$ for 28 days. Their results showed that AR-13324 $0.02 \%$ was less effective in terms of lowering $\mathrm{OH}$ than latanoprost by approximately $1 \mathrm{mmHg}$; the major safety finding was ocular hyperemia, which was more common for both concentrations of AR-13324 than for latanoprost.

Tanihara et al. ${ }^{(49)}$ studied the dose dependency and safety of the ROCK inhibitor K-115. Two hundred ten patients with POAG or OH were subdivided into four groups and were treated with K-115 at concentrations of $0.1 \%, 0.2 \%$, and $0.4 \%$ or placebo twice daily for eight weeks. The dose response of IOP reduction and the incidence of adverse events in the K-115 and placebo groups were investigated. The mean IOP reduction was $-3.1 \mathrm{mmHg}$ at $8 \mathrm{~h}$ after instillation in the $0.4 \%$ group, and all groups presented mild conjunctival hyperemia. The ROCK inhibitor SNJ-1656 was also demonstrated to be a safe hypotensive topical agent in human eyes ${ }^{(50)}$.

All recent human clinical trials have showed that mild-to-moderate conjunctival hyperemia is the main adverse effect of ROCK inhibitors ${ }^{(47-52)}$.

\section{CONCLUSION}

Unlike all other topical glaucomatous drugs, ROCK inhibitors target the trabecular pathway and act by increasing the aqueous humor outflow. This review has also described how these drugs enhance ocular blood flow and present neuroprotective effects as well as how they may inhibit scarring after glaucoma filtration surgery. This article also presents the newest clinical trials published in the literature on this topic, thus updating the current status of these drugs for use in glaucomatous eyes.

To date, several studies have demonstrated that the efficacy of ROCK inhibitors on $\mathrm{OH}$ is clinically and statistically significant in patients with $\mathrm{OH}$ and glaucoma. However, it remains to be seen in future clinical trials whether adverse side effects, such as conjunctival hyperemia, will lower patient compliance. Finally, further research is warranted to assess whether ROCK inhibitors can be synergistically used with other IOP-lowering drugs.

\section{REFERENCES}

1. Weinreb RN, Khaw PT. Primary open-angle glaucoma. Lancet. 2004;363(9422):1711-20. Comment in: Lancet. 2004;364(9442):1311-2.

2. Quigley HA, Broman AT. The number of people with glaucoma worldwide in 2010 and 2020. Br J Ophthalmol. 2006;90(3):262-7. Comment in: Br J Ophthalmol. 2006;90(3): 253-4.

3. Quigley HA. Glaucoma. Lancet. 2011;377(9774):1367-77.

4. Budenz DL, Barton K, Whiteside-de Vos J, Schiffman J, Bandi J, Nolan W, HerndonL, Kim H, Hay-Smith G, Tielsch JM; Tema Eye Survey Study Group. Prevalence of glaucoma in an urban West African population: the Tema Eye Survey. JAMA Ophthalmol. 2013;131(5):651-8

5. The Advanced Glaucoma Intervention Study (AGIS):7. The relationship between control of intraocular pressure and visual field deterioration. The AGIS Investigators. Am J Ophthalmol. 2000;130(4):429-40. Comment in: Am J Ophthalmol. 2000;130(4):490-1.
6. Heijl A, Leske MC, Bengtsson B, Hyman L, Hussein M; Early Manifest Glaucoma Trial Group. Reduction of intraocular pressure and glaucoma progression: results from the early manifest glaucoma trial. Arch Ophthalmol. 2002;120(10):1268-79. Comment in: JAMA. 2002;288(20):2607-8. Optom Vis Sci. 2002;79(12):741-2. Arch Ophthalmol. 2002;120(10):1371-2

7. Lichter PR, Musch DC, Gillespie BW, Guire KE, Janz NK, Wren PA, Mills RP; CIGTS Study Group. Interim clinical outcomes in the Collaborative Initial Glaucoma Treatment Study comparing initial treatment randomized to medications or surgery. Ophthalmology. 2001;108(11):1943-53. Comment in: Ophthalmology. 2003;110(2):249; author reply 249. Ophthalmology. 2001;108(11):1939-40.

8. Kass MA, Gordon MO, Gao F, Heuer DK, Higginbotham EJ, Johnson CA, Keltner JK, Miller JP, Parrish RK, Wilson MR; Ocular Hypertension Treatment Study Group. Delaying treatment of ocular hypertension: the ocular hypertension treatment study. Arch Ophthalmol. 2010;128(3):276-87. Comment in: Arch Ophthalmol. 2010;128(3):363-4.

9. Robin AL, Burnstein Y. Selectivity of site of action and systemic effects of topical alpha agonists. Curr Opin Ophthalmol. 1998;9(2):30-3.

10. Watanabe K, Chiou GC. Action mechanism of timolol to lower the intraocular pressure in rabbits. Ophthalmic Res. 1983;15(3):160-7.

11. Mincione F, Scozzafava A, Supuran CT. The development of topically acting carbonic anhydrase inhibitors as anti-glaucoma agents. Curr Top Med Chem. 2007;7(9):849-54.

12. Linden C, Alm A. Prostaglandin analogues in the treatment of glaucoma. Drugs Aging. 1999;14(5):387-98.

13. Honjo, M, Inatani, M, Kido, N, Sawamura, T, Yue, BY, Honda, Y, et al. A myosin light chain kinase inhibitor, ML-9, lowers the intraocular pressure in rabbit eyes. Exp Eye Res. 2002;75(2):135-42.

14. Tokushige $H$, Inatani M, Nemoto S, Sakaki H, Katayama K, Uehata M, et al. Effects of topical administration of Y-39983, a selective rho-associated protein kinase inhibitor, on ocular tissues in rabbits and monkeys. Invest Ophthalmol Vis Sci. 2007:48(7):3216-22.

15. Hirata A, Inatani M, Inomata Y, Yonemura N, Kawaji T, Honjo M, et al. Y-27632, a Rho- associated protein kinase inhibitor, attenuates neuronal cell death after transient retinal ischemia. Graefes Arch Clin Exp Ophthalmol. 2008;246(1):51-9.

16. Tura A, Schuettauf F, Monnier PP, Bartz-Schmidt KU, Henke-Fahle S. Efficacy of Rho-kinase inhibition in promoting cell survival and reducing reactive gliosis in the rodent retina. Invest Ophthalmol Vis Sci. 2009:50(1):452-61.

17. Sugiyama T, Shibata M, Kajiura S, Okuno T, Tonari M, Oku H, et al. Effects of fasudil, a rho-associated protein kinase inhibitor, on optic nerve head blood flow in rabbits. Invest Ophthalmol Vis Sci. 2011;52(1):64-9.

18. Tamm ER. The trabecular meshwork outflow pathways: structural and functiona aspects. Exp Eye Res. 2009;88(4):648-55.

19. Johnson M. What controls aqueous humor outflow resistance? Exp Eye Res. 2006 82(4):545-57.

20. Bill A, Phillips Cl. Uveoscleral drainage of aqueous humor in human eyes. Exp Eye Res. 1971;12(3):275-81.

21. Zhou EH, Krishnan R, Stamer WD, Perkumas KM, Rajendran K, Nabhan JF, et al. Mechanical responsiveness of the endothelial cell of Schlemm's canal: scope, variability and its potential role in controlling aqueous humour outflow. J R Soc Interface. 2012; $9(71): 1144-55$

22. Maepea O, Bill A. Pressures in the juxtacanalicular tissue and Schlemm's canal in monkeys. Exp Eye Res. 1992; 54(6):879-83.

23. Lutjen-Drecoll E. Functional morphology of the trabecular meshwork in primate eyes. Prog Retin Eye Res. 1999;18(1):91-119.

24. Gabelt BT, Kaufmann PL. Changes in aqueous humor dynamics with age and glau coma. Prog Retin Eye Res. 2005;24(5):612-37.

25. Llobet A, Gasull X, Gual A. Understanding trabecular meshwork physiology: a key to the control of intraocular pressure? News Physiol Sci. 2003;18:205-9.

26. Wiederholt M, Thieme H, Stumpff F. The regulation of trabecular meshwork and ciliary muscle contractility. Prog Retin Eye Res. 2000;19(3):271-95.

27. De Kater AW, Shahsafaei A, Epstein DL. Localization of smooth muscle and nonmuscle actin isoforms in the human aqueous outflow pathway. Invest Ophthalmol Vis Sci. 1992;33(2):424-9.

28. Nakamura Y, Hirano S, Suzuki K, Seki K, Sagara T, Nishida T. Signaling mechanism of TGF-beta1-induced collagen contraction mediated by bovine trabecular meshwork cells. Invest Ophthalmol Vis Sci. 2002;43(11):3465-72.

29. Epstein DL, Rowlette LL, Roberts BC. Acto-myosin drug effects and aqueous outflow function. Invest Ophthalmol Vis Sci. 1999:40(1):74-81.

30. Wiederholt M. Direct involvement of trabecular meshwork in the regulation of aqueous humor outflow. Curr Opin Ophthalmol. 1998:9(2):46-9.

31. Rao PV, Deng P, Sasaki Y, Epstein DL. Regulation of myosin light chain phosphorylation in the trabecular meshwork: role in aqueous humor outflow facility. Exp Eye Res 2005:80(2):197-206

32. Inatani M, Tanihara $H$, Katsuta $H$, Honjo M, Kido N, Honda Y. Transforming growth factor-beta 2 levels in aqueous humor of glaucomatous eyes. Graefes Arch Clin Exp 2001;239(2):109-13.

33. Picht G, Welge-Luessen U, Grehn F, Lutjen-Drecoll E. Transforming growth factor beta 2 leves in the aqueous humor in different types of glaucoma and the relation to filtering bleb development. Graefes Arch Clin Exp Ophthalmol. 2001;239(3):199-207.

34. Tripathi RC, Li J, Chan WF, Tripathi BJ. Aqueous humor in glaucomatous eyes contains an increased level of TGF-beta2. Exp Eye Res 1994;59(6):723-7. 
35. Tezel G, Kass MA, Kolker AE, Becker B, Wax MB. Plasma and aqueous humor endothelin levels in primary open-angle glaucoma. J Glaucoma 1997:6(2):83-9.

36. Pfitzer G. Invited review: regulation of myosin phosphorylation in smooth muscle. J Appl Physiol. 2001;91(1):32-9.

37. Liao JK, Seto M, Noma K. Rho kinase (ROCK) inhibitors. J Cardiovasc Pharmacol 2007 50(1):17-24.

38. Rao PV, Deng PF, Kumar J, Epstein DL. Modulation of aqueous humor outflow facility by the Rho kinase-specific inhibitor Y27632. Invest Ophthalmol Vis Sci. 2001:42(5): 1029-37. Erratum in: Invest Ophthalmol Vis Sci. 2001;42(8):1690.

39. Honjo M, Tanihara H, Inatani M, Kido N, Sawamura T, Yue BY, et al. Effects of rho-associated protein kinase inhibitor Y-27632 on intraocular pressure and outflow facility. Invest Ophthalmol Vis Sci 2001;42(1):137-44

40. Tamura M, Nakao H, Yoshizaki H, Shiratsuchi M, Shigyo H, Yamada H, et al. Development of specific Rho-kinase inhibitors and their clinical application. Biochim Biophys Acta. 2005; 30;1754(1-2):245-52

41. Honjo M, Inatani M, Kido N, Sawamura T, Yue BY, Honda Y, et al. Effects of protein kinase inhibitor, HA1077, on intraocular pressure and outflow facility in rabbit eyes. Arch Ophthalmol. 2001;119(8):1171-8

42. Tokushige H, Waki M, Takayama Y, Tanihara H. Effects of Y-39983, a selective Rho-associated protein kinase inhibitor, on blood flow in optic nerve head in rabbits and axonal regeneration of retinal ganglion cells in rats. Curr Eye Res. 2011;36(10):964-70.

43. Honjo M, Tanihara H, Kameda T, Kawaji T, Yoshimura N, Araie M. Potential role of Rho-associated protein kinase inhibitor Y-27632 in glaucoma filtration surgery. Invest Ophthalmol Vis Sci. 2007;48(12):5549-57

44. Stefansson E, Pedersen DB, Jensen PK, la Cour M, Kiilgaard JF, Bang K, et al. Optic nerve oxygenation. Prog Ret Eye Res. 2005;24(3):307-32.
45. Rao VP, Epstein DL. Rho GTPase/Rho kinase inhibition as a novel target for the treatment of glaucoma. Bio Drugs. 2007:21(3):167-77.

46. Meyer-ter-Vehn T, Sieprath S, Katzenberger B, Gebhardt S, Grehn F, Schlunck G. Contractility as a prerequisite for TGF-beta-induced myofibroblast transdifferentiation in human tenon fibroblasts. Invest Ophthalmol Vis Sci. 2006;47(11):4895-904.

47. Arnold JJ, Hansen MS, Gorman GS, Inoue T, Rao V, Spellen S, et al. The effect of Rho-associated kinase inhibition on the ocular penetration of timolol maleate. Invest Ophthalmol Vis Sci. 2013;54(2):1118-26.

48. Bacharach J, Dubiner HB, Levy B, Kopczynski CC, Novack GD; AR-13324-CS202 Study Group. Double-masked, randomized, dose-response study of AR-13324 versus latanoprost in patients with elevated intraocular pressure. Ophthalmology. 2015;122(2): 302-7

49. Tanihara H, Inoue T, Yamamoto T, Kuwayama Y, Abe H, Araie M; K-115 Clinical Study Group. Phase 2 randomized clinical study of a Rho kinase inhibitor, K-115, in primary open-angle glaucoma and ocular hypertension. Am J Ophthalmol. 2013:156(4):731-6.

50. Tanihara H, Inatani M, Honjo M, Tokushige H, Azuma J, Araie M. Intraocular pressure-lowering effects and safety of topical administration of a selective ROCK inhibitor, SNJ-1656, in healthy volunteers. Arch Ophthalmol. 2008;126(3):309-15.

51. Tanihara H, Inoue T, Yamamoto T, Kuwayama Y, Abe H, Araie M; K-115 Clinical Study Group. Phase 1 clinical trials of a selective Rho kinase inhibitor, K-115. JAMA Ophthalmol. 2013;131(10):1288-95.

52. Williams RD, Novack GD, van Haarlem T, Kopczynski C; AR-12286 Phase 2A Study Group. Ocular hypotensive effect of the Rho kinase inhibitor AR-12286 in patients with glaucoma and ocular hypertension. Am J Ophthalmol. 2011;152(5):834-41.

\title{
VI Simpósio de Atualização do Hospital Banco de Olhos de Porto Alegre
}

\author{
1 e 2 de abril de 2016 \\ Sede da AMRIGS \\ Porto Alegre - RS
}

Informações:

Site: www.hbo.br/simposio

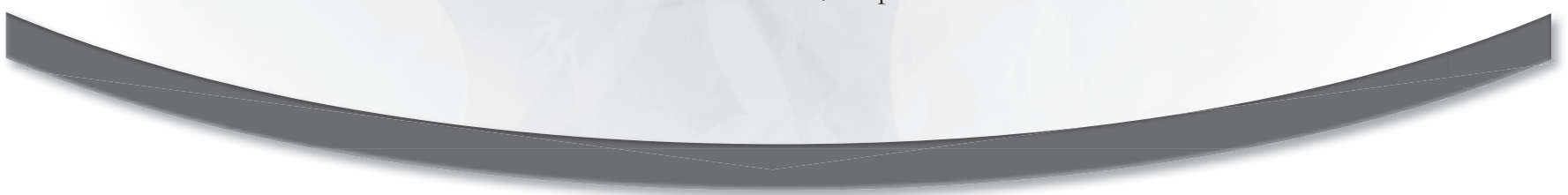

